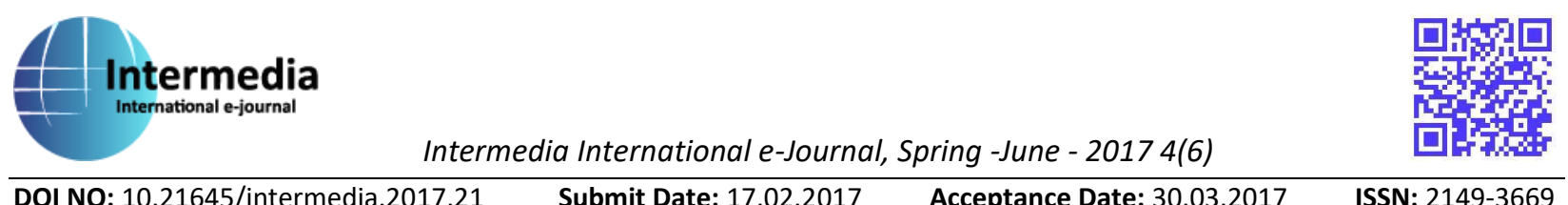

\title{
SPACE FOR PUBLIC CONTRIBUTION/OPINION PROVIDED BY THE LOCAL NEWSPAPERS - A CRITICAL STUDY
}

\author{
Arup Guchhait ${ }^{1}$ \\ Communicating Author Research Scholar, University of Calcutta and Public Relation Officer, \\ West Bengal Pollution Control Board \\ Prof. Dr. Tapati Basu² \\ Professor, Department of Journalism \& Mass Communication, \\ University of Calcutta \\ Tushar Kanti Ghara ${ }^{3}$ \\ Joint Director of Public Instruction, Government of West Bengal;
}

\begin{abstract}
Media has an enormous role in communicating information in various kind. Particularly, the print media is serving society strongly with their evolution in various fields including technological aspects. Within the steep competition each media wants to hold theirown audience with continuous innovative items. Environment is such a contemporary subject which has a fair demand. So the space is so valuable. In this study, the status of the English and the Bengali dailies in connection with environmental journalism, especially the space provided for public contribution/opinion has been scrutinized. This may be concluded that though the limited space has been allotted for public contribution/opinion by the newspapers, English dailies comparatively give maximum importance the public opinion, especially the Telegraph.
\end{abstract}

Key Words: newspaper, opinion, space

\section{Introduction}

When Timur Lang conquered Nasir-ud-Din Mahmud Shah Tughluq's forces in the battle for Delhi on 17 December $1398,{ }^{1}$ there were no mass media in India. For this reason, people across the country could not get such important news of that time in a quick period of time. Indian remained ignorant of a bloody destruction within the Delhi city walls was occurred and even three days after this massacre, it was alleged that the Delhi city smelled of rotting bodies of its dwellers with their heads being founded like structures and the bodies left as food for the birds. But media could have provoked people to resist foreign penetration and that might create a new direction of the Indian history. Mass media could not highlight the demolition of Delhi and boundless loss of the resource.

On the other hand, within minutes of the dreaded earthquake in Nepal in 2015, mass media started to show the devastation in minutes of possible details. Mainly the electronic media showcased the live experience of

\footnotetext{
${ }^{1}$ (Department of Environment, Government of West Bengal),[Male, Mobile no. 9830585308, Email: garup2006@gmail.com]

2 [Female, Mobile no. 9831081407, Email: tapatiindia@gmail.com, Website: www.tapatibasu.com]

${ }^{3}$ [Male, Mobile no. 9433062226, Email: tkghara@gmail.com]
} 
the tourists and Nepalese. Within few hours journalist from across the globe reached Nepal to cover the fatal incident. Watching that incurable incident at different parts of Nepal on mass media, several countries including India and some international voluntary organisations offered their assistance to save the humanity.

Now, everybody intends to create wider impact at a time spread all over the world. The days of direct communication between one individual and another are gone. Modern society has invented such a miraculous process with the help of wonderful devices to transmit messages even to the remotest corner of the world with thrilling speed. This process is known as mass communication and the media through which messages are sent as mass media.

The newspaper is one of the early communication instruments of the society. ${ }^{2}$ Now, the newspaper is one of the major components of a modern society. Newspapers of a modern society always try to communicate the current news of across the world. The current trend of the major dailies is to employ journalists and photojournalists to cover all the possible events/programmes from all over the places. The major newspapers also subscribed news/photographs from news-agencies of different countries.

Mainly the journalists are specially trained in journalistic writing which is totally different from literature writing. Good journalism always demands a proficient writing. The proficient writing always involves the easy and fluent expertise of correct language and smartness. Basically, every journalist should harmonise the frame of mind of the readers through his or her writing. They act as a mirror of the society and disseminate information meticulously which helps developing a public opinion on any issue. Similarly, photo-journalists are also exceptionally trained to click news-photographs having motion and news. Selection of photographs goes through several check posts.

The roles of the newspapers are significantly increasing day by day in modern time. Newspapers are also guiding in the promotion of trade and business. Writing on commerce, entertainment, culture, sports, politics, health, crime, law, science, environment and other subject enrich people regular basis. In general, newspapers inform people about the promotion of any products, job vacancies, admission in educational institutes, study materials, fashion, food, marketing facilities, hospitality, bullion reports, meteorological reports etc.

The 'letter to the editor' is now treated as an important section of modern newspapers. In this section, the editorial department can highlight readers' grievances or appreciation about any news, article, feature, photograph or any event of the society. In essence, 'letter to the editor' section of the newspaper is opinion column through which journalists can get touch with the readers. In a democratic modern society, the audience can select media which fulfil their desires, believes, needs, interests and even myths. ${ }^{4}$ Basically, the mass media send messages or news for receiver or audience in a very professional way. Each mass media house is often professional communicator, not a single person. ${ }^{5}$

Media research is also involved in the presentation of news. Mainly, the mass communication is complicated than face to face communication. While mass media put information across a vast area, there is no sureness whether the information will be served to their demand or be appreciated by the audience. Mass communication is obviously an art. No mass media can fulfil the varied demand of its audience because it is quiet impossible to assess the mental ability of all individual audience to whom an information is provided. So it needs Journalistic experience and media research only encourages mass media to provide the most acceptable information. The impact of such information cannot be assessed instantaneously. 
Each mass media-house respects its audience for whom they serve news. Each mass media-house always tries to make its own audience and to make a special bonding with them. No media-house expects to lose its audience. Media-houses take participate in 'rat race' to increase their audience size. To increase audience size, media-houses used to take a different kind of tricky policies. Finally, reasonable size of the audience depends on news-content. Media-houses always prefer to select that type of news which is mostly enjoyed by the audience. So, a distinct type of news-style, news-presentation are seen in the case of media-house to media-house. On the other hand, audience size denotes the popularity of the respective mass media. And popularity provides commercial success in favour of the respective mass media.

Mass media always play with the behaviour of the audience. Mass media possess such strength to induce human behaviour. It is believed that the human behaviour is one of the complex matters in this world. So, this is not an easy task to crack the human behaviour. It can influence people to take necessary steps to lead better living. Communication technique of mass media involves several psychological and behavioural aspects which manipulate our behaviour, our likings. The level of manipulation depends on journalists' intelligence, schooling, character, fondness, analytical mind, sensitiveness etc. of an audience. Like other professions, journalism cannot be necessarily evaluated so straightforwardly. ${ }^{6}$

This is clear that all the information provided by the mass media do not influence all people. Any individual prefers only that information which has harmony with the attitudes, believes and values of that person. Different social factors also take effect on mass communication. On the other hand, media also help people to set out agendas by providing issues to think about. ${ }^{7}$ Mass media encourages people to participate in any social or political change. So, this can be easily said that the mass media has an intense impact on people to build an informative society.

\section{Influence of public opinion}

The influence of public opinion is not restricted to politics only. It is now a strong instrument in many other fields like sports, entertainment, literature, fashion, art \& culture, marketing, economics, public relation, environment etc. Public opinion is summative of the individual views, attitudes and beliefs about a specific subject, expressed by a reasonable proportion of a society. The great American sociologist Charles Horton Cooley mentioned in his writing in 1918 that society is a development continuing to shape and reshape by way of individuals, groups, patterns, and institutions. In this process, public opinion is a very important component. Cooley pointed out in his writing that public opinion is a process of interaction and mutual persuasion rather than a state of the broad accord. $^{89}$ The American political scientist V.O. Key described public opinion in 1961 as "opinions held by private persons which governments find it prudent to heed." ${ }^{10}$ In his unique publication 'Public Opinion' (1922), the 'Father of Modern Journalism' Walter Lippmann observed democracies and mentioned that "there have been skilled organisers of opinion who understood the mystery well enough to create majorities on election day."Public opinion is defined differently on the basis of different perspectives of modern times and it is universally accepted now. $^{11} 12$

The term 'public opinion' was first popularised by Jacques Necker, the finance minister for Louis XVI. On the eve of the French Revolution, Necker mentioned repeatedly in his writings that "public credit depended upon the opinions of holders and buyers of government securities about the viability of the royal administration". ${ }^{13}$ The origins of the modern idea of public opinion are found in the liberal democratic theories of ancient Greece. ${ }^{14}$ Conceptualization of public opinion developed during the Enlightenment, but the separate concepts of the public and opinion have also been developed in ancient years and having so many denotations. ${ }^{15}$ The opinion was used in two senses i.e. in the case of decision and status. Finally, both the senses communicate the concept of judgement. On the other hand, the term public derived from the Latin"populous" or "policies" and in general sense, it means 
mass population involving in the subject of shared interest. But now, the meaning of public is different in various subjects. In political science and history, the meaning of public is a population of individuals involving mainly with civic affairs. In social psychology, marketing, and public relations, the meaning of public depends on situational demand. ${ }^{16}$ In public relations and communication science, public is the entirety of special groups which is one of the more unclear perceptions in the field. A different concept of the meaning of public persists in sociology. Although different definitions have been formulated by the experts, ambiguity in regards to the definition of the public has emerged from the early $20^{\text {th }}$ century with the concepts of the reader, spectator, viewer audience, market, stakeholder, advertiser, sponsor, patron, community, media, constituency, group etc.

Today's political analysts believe that public opinion influence particularly on the development of government policy. Some social scientists explained public opinion as comparable to the national will. Basically, sociologists have considered public opinion as for the result of social interaction and communication. Sociologists have also other argument that possibility of having many different public opinions on a particular issue at the same time. It is also true that possibility of a continuous change of public opinion is high. One type of public opinion may have a strong impact but this does not rule out the existence of other public opinions. The sociologists always recognise the significance of public opinion that has little or nothing to do with government. ${ }^{17}$

There are so many views regarding the formation of public opinion. Scholars are divided for their views of conditions to build a public opinion. Numerous conditions for the formation of public opinion have been discussed for last two centuries. Accumulating all the thoughts of different scholars of public opinion as they described it, minimum four conditions must be fulfilled: (a) should have an issue, (b) should have opinions of reasonable number of individuals on the issue, (c) should have minimum extracted harmony among some of the opinions, (4) this harmony should exercise influence directly or indirectly.

It is now a trend to collect comments from locals who belong to the place of occurrence, witnesses who were present at the moment of the occurrence of the event, experts on the subject, historians who has an experience of such type of events, administrators who may advocate the events, police officers who may investigate the source of reality, government officials who may highlight the proper picture or planning. These comments increase the credibility of the news as well the media. The audience can judge or visualise the event and accordingly try to relate this to his or experience. Moreover, comments or letter to the editor may set agenda. This is not an easy job to collect proper comments because all the sources are not enough skilled or experienced to narrate their comment as required by a media. This should be mentioned that making comments on the specific issue needs proper knowledge, education, thinking and other factors. Government servants are always shaky to comment for their service regulation and they are always sceptical in this regard. But it depends on country to country. In India, government servants used to avoid media especially they keep away themselves from any debatable issue. Political leaders and heads of the institutions occasionally give their comments on specific issues in India. On the other hand, locals or witnesses sometimes show their over-reactions in any event and they often deviate the proper lines of facts.

In the case of local newspapers mainly the nine newspapers published from Kolkata, which I have taken for my research, are publishing or carrying comments along with hard reporting regular basis. Beside that these local nine newspapers also published 'letters to the editor' prominently.

'Letters to the editor' is a very important component of a newspaper. Popular newspapers used to get more and more number of such letters. Sometimes, it is a problem for popular newspapers to select the most adorable letters from the hip of the letters to publish. 'Letters to the editor' is such a platform where the readers can share their opinions directly; can oppose or support an action taken by the government or any institution; can 
request or direct the elected body or the government to give attention to a problem; can correct and clarify facts in a news story published previously; can encourage editors to cover an overlooked issue or event; can insist other readers to support your cause. 'Letters to the editor' are really very effective in the case of local newspapers.

Every newspaper has a different policy to handle the 'letters to the editor'. Some newspapers do not publish letter carrying any debatable issue. Some newspapers prefer such letters having the news collected from a remote area. Some newspapers always prefer letters having such content which will initiate a debate among the readers. In a competitive market, each newspaper used to explore the new field of news, features etc. regular basis. Naturally, space for 'letters to the editor' is shrinking day by day for providing space for different kind of news items. Fewer numbers of such letters are published today. Even, popular newspapers can't provide space for letters every day. Even the newspapers are restricting words for such letters. So, it is understandable that the function of an editor for selecting a letter(s) to be published is becoming harder.

All the readers are not focused on writing letters. A section of people is keen to write letters to the editor. They want to communicate their views basically. They maintain some gentleman's norms understanding the limitations of a newspaper. They used to write precisely so that an editor does not cut out important portions of their letter. They also mention their address and telephone numbers so that an editor can verify who wrote the letter or any clarify anything of the letter. Many times readers requested editor to hide their name and address for security reasons or they use the pseudo name for the same cause. Moreover, readers who write letters to the editor, used to mention his or her credentials to prove his or her knowledge of the subject or topic.

Editors always prefer local issues mainly affecting reader's lives and community on a regular basis. If it is a national issue, editors try to find out the factors which affect people exceptionally. Editors select those letters having the informative background before exploring the main issue which is being covered recently in news and without having any complexity. Letters on the issues which are not in news are rarely published by the newspapers.

Considering all above, now the questions of this study are: Do the local newspapers publish a public opinion on any environmental issue adequately? Which type of newspapers Bengali or English dailies are more trustworthy on publishing statements/opinion of readers, general mass, politicians, experts, scientist, NGOs, environmentalists and other stakeholders? What is the status of Local newspapers as a whole in case of providing space for public contribution/opinion? Which newspaper publish the most number of the public opinion?

\section{Conceptualization}

Environmental news published in Kolkata Dailies have been classified into several "News Type". Among them, only major seven (07) categories like comments, editorial, features, general news, hard news, letter, photo news have been studied here. Usually, all the categories of news have their own characteristics. Only any doubt or confusion may be raised between general news and hard news. News of both the categories has different news value. News value depends on four (04) basic factors like importance, proximity, size and timeliness. ${ }^{18}$

General news is more casual in nature than hard news.

Hard news always possesses the better significance of effectiveness, timely actions and results than any general news. Though, this may be mentioned that the gap between these two categories is not so prominent. Even also, it is not an easy job to differentiate both the categories every time.

Carrying opinion of the citizens or audience is perhaps the most treasured part of the mass media in this information age. It is now very easy to get information about the actions taken by the government from different mass media. It is also easy to get and share opinions on the specific issue. The audience can harmonise opinion of 
one's own. In most of the cases, mass media take a nonpartisan stand and accept opinions based on the different school of thoughts. In the case of electronic media, the debate on the specific issue is frequently seen. Online sources like blogs, emails exclusively handled by any individual are the key components of such debates in electronic media. In print media, 'letter to the editor' is the only platform to share the readers' opinions. Sometimes print media itself feel to find the opinion of readers on any issue. In that case, print media collect opinion by interviewing experts, concerned people and general mass.

Editorial is the mirror of a newspaper and it projects the viewpoint of the newspaper on a particular policy. ${ }^{19}$ Usually, a group of senior journalists are involved in writing daily editorial. Some of the newspapers used to publish more than one editorial. Specialised features and other columns are also found in local print media regular basis. The feature has a great importance in all newspapers. News does not carry previous records, future consequences, and does not have documentation value etc. The feature focuses on overview details and possesses documentation value.

All photographs which were published in nine prominent dailies during January to March, 2005 have been divided into eight (08) further types like Colour(Natural), Black \& White (Natural), Colour (Symbolic), Black \& White (Symbolic), Collage (Colour), Collage (Black \& White) Sketch (Colour), Sketch (black \& White).

Published news was also categorised into three (03) i.e. local, national and international vide the content of the news in respect of the place of interest.

\section{Methodology}

Nine prominent newspapers of five long years (edition of $1^{\text {st }}$ January, 2005 to $31^{\text {st }}$ December, 2010) have been monitored critically. In the category of prominent dailies, following publications published from Kolkata have been studied:-

1. The Telegraph (English)

2. The Statesman (English)

3. The Times of India (English)

4. Hindustan Times (English)

5. Anandabazar Patrika (Bengali vernacular)

6. Bartaman (Bengali vernacular)

7. Aajakal (Bengali vernacular)

8. Sambad Pratidin (Bengali vernacular)

9. Ganashakti (Bengali vernacular)

These are the most populated and widely circulated newspapers during 2005 and 2010 in Kolkata. One glimpse of average qualifying circulation of those newspapers are mentioned below:-

\begin{tabular}{|c|l|c|c|}
\hline SR. NO. & \multicolumn{1}{|c|}{ NEWSPAPER } & JANUARY - JUNE 2010 & JULY - DECEMBER 2010 \\
\hline 1. & The Telegraph & $4,73,690$ & $4,81,755$ \\
\hline 2. & The Statesman & $1,72,195$ & Not accepted by ABC \\
\hline 3. & The Times of India & $3,93,587$ & $4,06,133$ \\
\hline 4. & Hindustan Times & 60,000 & 60,000 \\
\hline 5. & Anandabazar Patrika & $11,73,751$ & $11,85,779$ \\
\hline 6. & Bartaman & $4,85,449$ & $4,88,425$ \\
\hline 7. & Aajakal & $1,81,431$ & $1,81,353$ \\
\hline 8. & Sambad Pratidin & $3,06,644$ & $3,06,337$ \\
\hline 9. & Ganashakti & $1,51,822$ & $1,57,502$ \\
\hline
\end{tabular}


\{Source: Audit Bureau of Circulations $(A B C)$, excepting the data of Hindustan Times\}

To find the status of media coverage and the current trends in local print media coverage of environmental news in local leading print media, the news items published in aforesaid nine different prominent dailies were collected according to a welldefined sampling procedure through which a broad spectrum of environmental science categories may be covered for long 72 months during $1^{\text {st }}$ January, 2005 to $31^{\text {st }}$ December, 2010. No promotional feature has been considered.

This was a very sturdy task to organise all the information, which has a significant position in this research. All the available paper clippings on environment related news published in previously mentioned newspapers for long 72 months during $1^{\text {st }}$ January, 2005 to $31^{\text {st }}$ December, 2010 have been organised month wise so that the convenient information can be marked out easily. All the information including different "News Type" have been analysed by specially made software prepared on access platform.

\subsection{A. Explanation: 1}

Date wise total available news published in nine different newspapers have been shown in the Table -1 and Chart - 1. A total of 20,697 news has been published during $1^{\text {st }}$ January, 2005 to $31^{\text {st }}$ December, 2010. Out of this, a total of 9,503 and 11,194 news published in five Bengali and four English dailies respectively.

\subsection{B. Observation:}

1. News in English published in more in number on all the days than news in Bengali excepting 17th.

2. Highest numbers (897) of total news (Bengali + English) were published on a single day i.e. $5^{\text {th }}$.

3. Maximum numbers (514) of English news were published on a single day i.e. $5^{\text {th }}$.

4. Maximum numbers (414) of Bengali news were published on a single day i.e. $6^{\text {th }}$.

5. Three main sets of continuous days (a) $5^{\text {th }}$ to $10^{\text {th }}$ (where minimum 386 English news and 325 Bengali news have been published), (b) $18^{\text {th }}$ to $20^{\text {th }}$ (where minimum 365 English news and 318 Bengali news have been published) and (c) $22^{\text {nd }}$ to $24^{\text {th }}$ (where minimum 359 English news and 278 Bengali news have been published)have been identified.

\subsection{Remarks:}

1. Four English dailies contributed more news than five Bengali dailies.

2. English dailies contributed at an average of 2,798.5 numbers of news per newspapers, while Bengali dailies contributed at an average of 1,900.6 numbers of news per newspapers.

3. English dailies contributed at an average of 5.109 numbers of news per day, while Bengali dailies contributed at an average of 4.337 numbers of news per day.

4. News in English published in more in number on all the days than news in Bengali excepting one day (14 ${ }^{\text {th }}$ ) and the maximum numbers (514) of news was published on a single day also in English.

5. So, this can be mentioned that the English dailies contributed more than the Bengali dailies.

\subsection{A. Explanation: 2}

Newspapers wise total available news published in nine different newspapers in 'Environmental Category' have been shown in the Table -2 and Chart - 2. A total of 20,697 news has been published during $1^{\text {st }}$ January, 2005 to $31^{\text {st }}$ December, 2010.

\subsection{B. Observation:}

1. News in 'Comments' and 'Institutional Effort' categories prominently leads the Chart - 2 and compete for each other neck to neck in the most of the newspapers as a whole. 
2. The highest number of total news $(4,568)$ were published in 'Comments' category.

3. The second highest number of total news $(4,154)$ were published in 'Institutional Effort' category.

4. Other than 'Comments' and 'Institutional Effort' categories, the total number of news of any other 'Category' did not touch even 2,000 number barriers.

5. News in 'Comments' category published better in number than any other categories in only The Times of India, The Telegraph and The Statesman.

6. News in 'Institutional Effort' category published better in number than any other categories in Sambad Pratidin, Hindustan Times, Ganashakti, Bartaman, Anandabazar Patrika and Aajkal.

7. The Times of India carried the maximum number of news $(1,141)$ in 'Comments' category.

8. No newspaper carried any category of news more than 741 news excepting 'Comments' category.

9. All the newspapers published environmental category news like in 'Environmental Law Practice' and 'Corruption / Inactiveness', 'Environment Management', 'Awareness / Public Grievance' and Biodiversity / Habitat / Urbanisation' categories also in significant numbers.

10. Most of the environmental categories could not touch 100 numbers in any newspapers during six years in time.

\subsection{Remarks:}

1. Environmental Categories like 'Comments' (22\% of total news) and 'Institutional Effort' (20\% of total news) obtained the first and second spots and these two categories are representing Environmental Main Categories like 'General Environment' and 'Environmental initiative_awareness' respectively.

2. This may be mentioned that all the newspapers preferred such news in more numbers, which were not directly associated with pollution or mitigation of pollution.

3. Dominancy of Environmental Categories likes 'Comments' and 'Institutional Effort' signifies that all the newspapers as a whole do not prefer negative news. Under 'Comments', various type of people made their statement which was directly or indirectly for the support of the environment. On the other hands, under 'Institutional Effort', numerous efforts were taken by the various kinds of institutions including state or central government and their bodies, educational institutions, research organisations etc. which denoted also directly or indirectly for the patronage of the environment.

4. News under 'Comments' was published high in number in The times of India, The Telegraph, The Statesman. In the case of Hindustan Times, News under 'Comments' were published almost same in number like news under 'Institutional Effort'.

5. It denotes that the English dailies are more trustworthy because they relied on statements/opinion of readers, general mass, politicians, experts, scientist, NGOs, environmentalists and other stakeholders.

\subsection{A. Explanation: 3}

Total available 20,697 news contributed by different sources ('Report By') published in nine different newspapers have been shown in the Table -3 and Chart -3 .

\subsection{B. Observation:}

1. Different percentage of news contributed by major 'Report By' like 'Staff Reporter' (5.58\%), 'Reporter by Name' (23.75\%), 'Public' (5.45\%), 'News Agency (India)' (11.96\%), 'House Correspondent' (14.07\%) and 'Bureau' (10.14\%).

2. The Telegraph published the second maximum $13.5 \%$ (369 out of 2,732 ) news contributed by 'Public'.

\subsection{Remarks:}


1. Different percentage of news contributed to major 'Report By' like 'Staff Reporter' (5.58\%), 'Reporter by Name' (23.75\%), 'Public' (5.45\%), 'News Agency (India)' (11.96\%), 'House Correspondent' (14.07\%) and 'Bureau' (10.14\%).

2. All the newspapers as a whole provide very limited space for public contribution/opinion.

3. The Telegraph published the second maximum $13.5 \%$ (369 out of 2,732 ) news contributed by 'Public'.

4. The Telegraph is such a newspaper which respects most the public opinion.

\section{Conclusion}

From the above study, this may be concluded that the local newspapers published from Kolkata afford very limited space for public contribution/opinion but English dailies comparatively provide maximum importance. Amongst the dailies, The Telegraphs is such English daily respects most the public opinion. Moreover, this may also find out the cause of providing less space by the local newspapers.

\begin{tabular}{|c|c|c|c|}
\hline Row Labels & Bengali & English & Grand Total \\
\hline 01 & 293 & 302 & 595 \\
\hline 02 & 289 & 372 & 661 \\
\hline 03 & 287 & 356 & 643 \\
\hline 04 & 304 & 347 & 651 \\
\hline 05 & 383 & 514 & 897 \\
\hline 06 & 414 & 463 & 877 \\
\hline 07 & 343 & 386 & 729 \\
\hline 08 & 358 & 413 & 771 \\
\hline 09 & 335 & 437 & 772 \\
\hline 10 & 325 & 418 & 743 \\
\hline 11 & 317 & 355 & 672 \\
\hline 12 & 297 & 377 & 674 \\
\hline 13 & 262 & 328 & 590 \\
\hline 14 & 332 & 310 & 642 \\
\hline 15 & 276 & 307 & 583 \\
\hline 16 & 301 & 337 & 638 \\
\hline 17 & 341 & 321 & 662 \\
\hline 18 & 318 & 379 & 697 \\
\hline 19 & 320 & 383 & 703 \\
\hline 20 & 323 & 365 & 688 \\
\hline 21 & 286 & 310 & 596 \\
\hline 22 & 324 & 359 & 683 \\
\hline 23 & 300 & 445 & 745 \\
\hline 24 & 278 & 386 & 664 \\
\hline 25 & 279 & 346 & 625 \\
\hline 26 & 256 & 295 & 551 \\
\hline 27 & 263 & 324 & 587 \\
\hline 28 & 299 & 366 & 665 \\
\hline 29 & 304 & 346 & 650 \\
\hline 30 & 298 & 339 & 637 \\
\hline 31 & 198 & 208 & 406 \\
\hline
\end{tabular}




\begin{tabular}{|c|c|c|c|}
\hline Grand Total & 9503 & 11194 & 20697 \\
\hline
\end{tabular}

Table 1

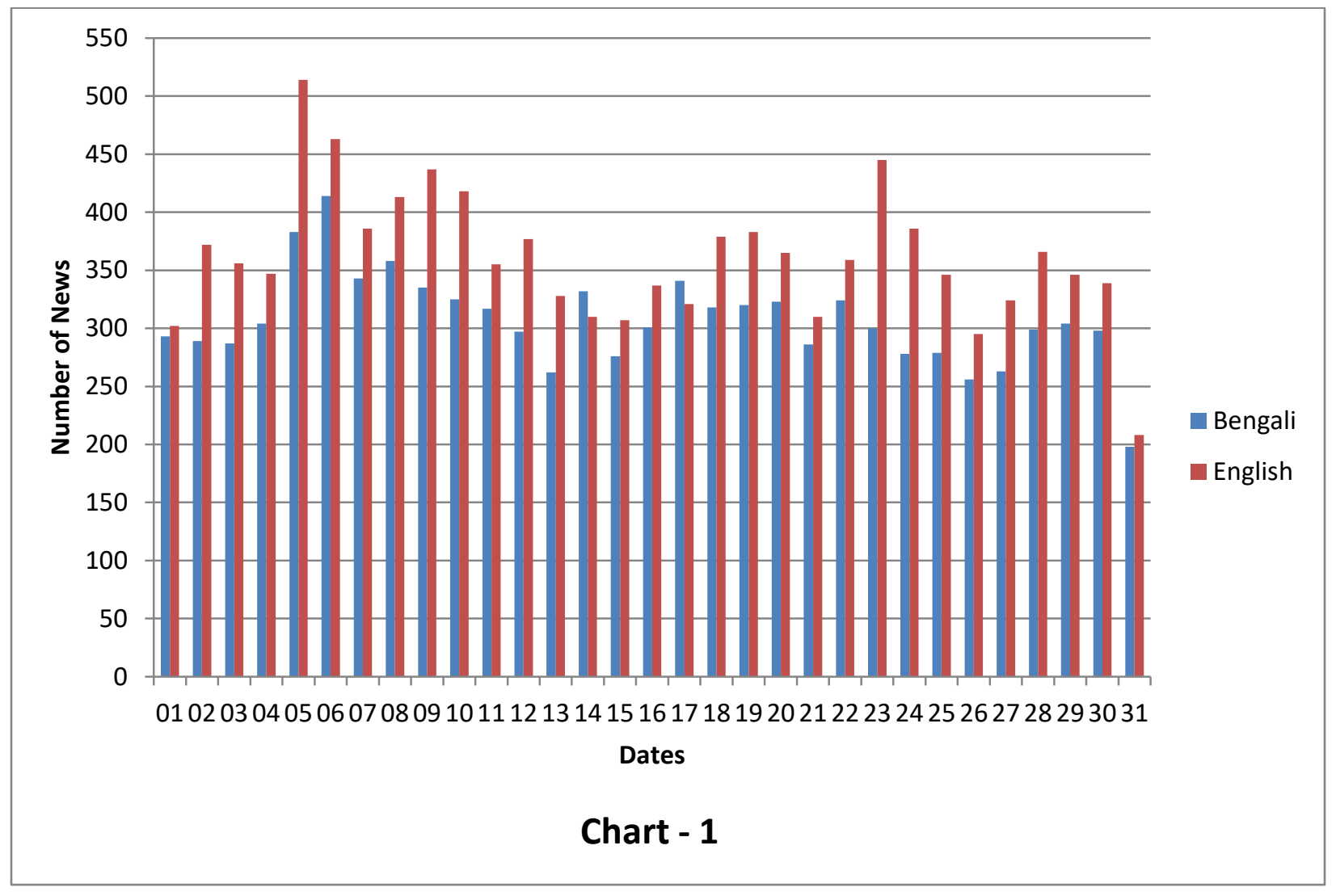

\begin{tabular}{|c|c|c|c|c|c|c|}
\hline Row Labels & $\begin{array}{l}\text { AWARENESS / } \\
\text { PUBLIC } \\
\text { GRIEVANCE }\end{array}$ & COMMENTS & $\begin{array}{l}\text { CORRUPTION / } \\
\text { INACTIVENESS }\end{array}$ & $\begin{array}{l}\text { ENVIRONMENTAL } \\
\text { LAW PRACTICE }\end{array}$ & $\begin{array}{l}\text { INSTITUTIONAL } \\
\text { EFFORT }\end{array}$ & $\begin{array}{l}\text { Grand } \\
\text { Total }\end{array}$ \\
\hline Aajkal & 103 & 325 & 33 & 142 & 333 & 1399 \\
\hline Anandabazar Patrika & 126 & 506 & 352 & 260 & 560 & 2897 \\
\hline Bartaman & 90 & 356 & 215 & 200 & 395 & 1910 \\
\hline Ganasakti & 133 & 251 & 57 & 106 & 360 & 1495 \\
\hline Hindustan Times & 124 & 570 & 150 & 156 & 594 & 2733 \\
\hline Sambad Pratidin & 129 & 368 & 121 & 169 & 407 & 1809 \\
\hline The Statesman & 86 & 373 & 85 & 104 & 330 & 1735 \\
\hline The Telegraph & 143 & 678 & 200 & 221 & 434 & 2732 \\
\hline
\end{tabular}




\begin{tabular}{|l|r|r|r|r|r|r|} 
The Times of India & 122 & 1141 & 249 & 203 & 741 & 3987 \\
\hline Grand Total & $\mathbf{1 0 5 6}$ & $\mathbf{4 5 6 8}$ & $\mathbf{1 4 6 2}$ & $\mathbf{1 5 6 1}$ & $\mathbf{4 1 5 4}$ & $\mathbf{2 0 6 9 7}$ \\
\hline
\end{tabular}

Table 2

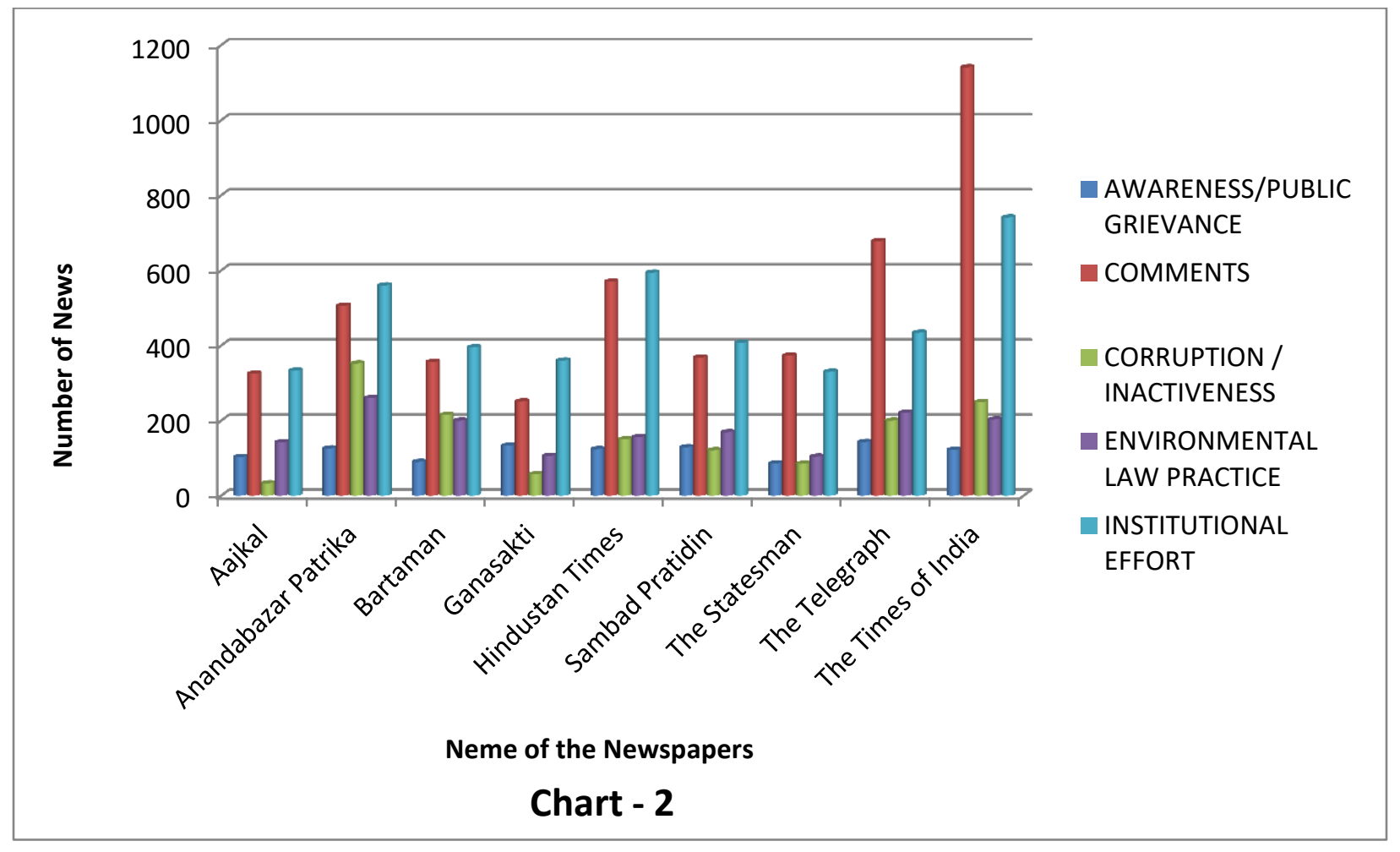

\begin{tabular}{|l|c|c|c|c|c|c|c|}
\hline Row Labels & Bureau & $\begin{array}{l}\text { House } \\
\text { Correspondent }\end{array}$ & $\begin{array}{l}\text { News } \\
\text { Agency } \\
\text { (India) }\end{array}$ & Public & $\begin{array}{l}\text { Reporter } \\
\text { by Name }\end{array}$ & $\begin{array}{l}\text { Staff } \\
\text { Reporter }\end{array}$ & $\begin{array}{l}\text { Grand } \\
\text { Total }\end{array}$ \\
\hline Aajkal & 732 & 19 & 86 & 178 & 207 & 7 & 1399 \\
\hline Anandabazar Patrika & 142 & 840 & 94 & 187 & 893 & 78 & 2897 \\
\hline Bartaman & 23 & 902 & 208 & 63 & 238 & 8 & 1910 \\
\hline Ganasakti & 35 & 662 & 65 & 62 & 212 & 12 & 1495 \\
\hline Hindustan Times & 132 & 456 & 84 & 26 & 945 & 6 & 2733 \\
\hline Sambad Pratidin & 85 & 18 & 63 & 104 & 349 & 701 & 1809 \\
\hline The Statesman & 41 & 3 & 762 & 63 & 290 & 6 & 1735 \\
\hline The Telegraph & 340 & 7 & 51 & 369 & 677 & 338 & 2732 \\
\hline The Times of India & 570 & 6 & 1063 & 78 & 1106 & & 3987 \\
\hline Grand Total & $\mathbf{2 1 0 0}$ & $\mathbf{2 9 1 3}$ & $\mathbf{2 4 7 6}$ & $\mathbf{1 1 3 0}$ & $\mathbf{4 9 1 7}$ & $\mathbf{1 1 5 6}$ & $\mathbf{2 0 6 9 7}$ \\
\hline
\end{tabular}


Table 3

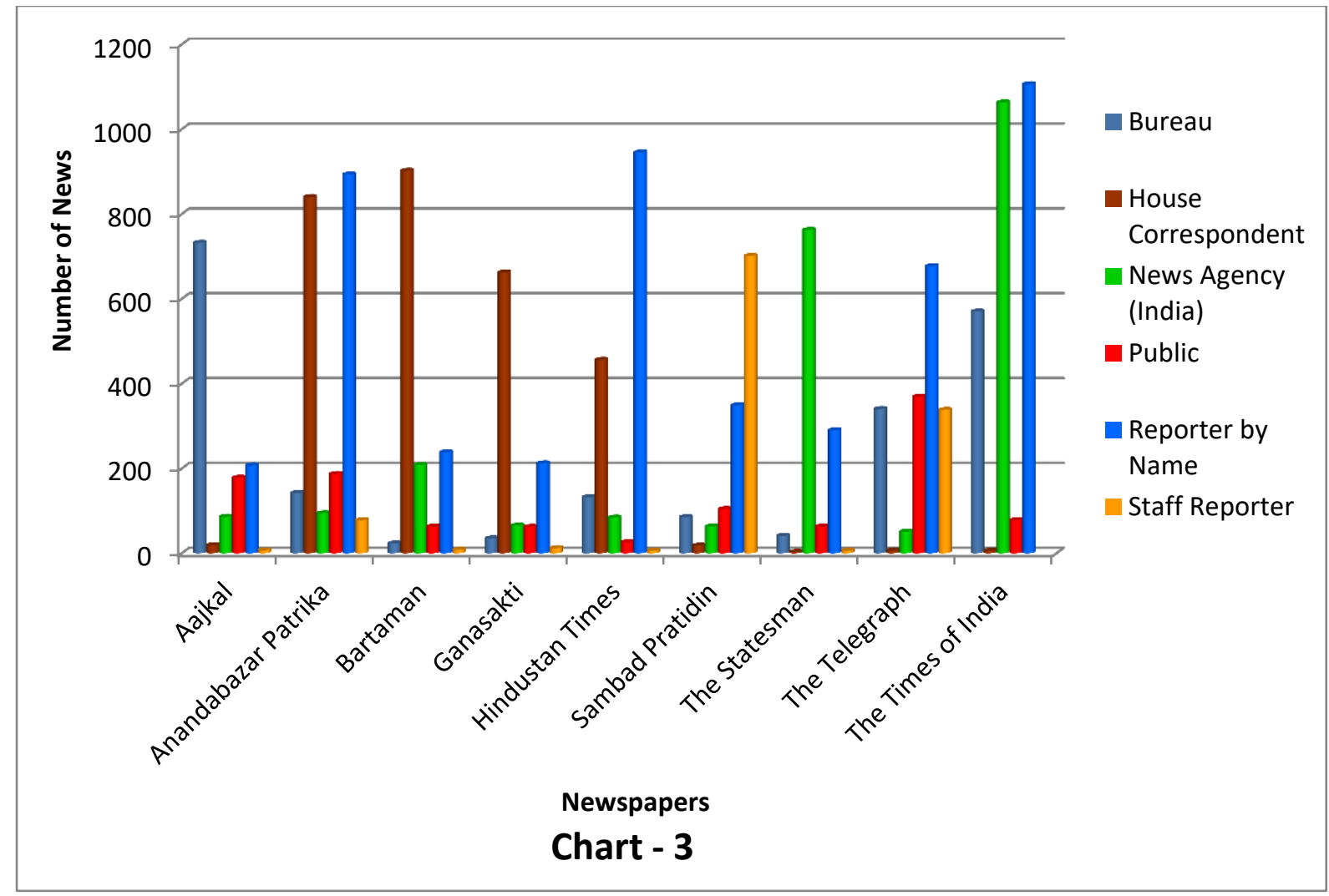

${ }^{1}$ Forbes Manz, Beatrice (April 1998). "Temür and the Problem of a Conqueror's Legacy". Journal of the Royal Asiatic Society. Vol. 8, No. 1 (Apr., 1998), pp. 21-41

${ }^{2}$ Shannon E. Martin and David A. Copeland, eds. (2003), The Function of Newspapers in Society: A Global Perspective, Praeger, p. 2

${ }^{3}$ Thomas Schroeder (2001), "The Origins of the German Press," in The Politics of Information in Early Modern Europe edited by Brendan Dooley and Sabrina Baron.

${ }^{4}$ Ghosh, Subir (1991), Mass Media Today, Profile Publishers, Calcutta

${ }^{5}$ Ghosh, Subir (1991), Mass Media Today, Profile Publishers, Calcutta

${ }^{6}$ Carr, C.F. and Stevens, F.E. (1946), Modern Journalism, Sir Isaac Pitman \& Sons Ltd, London

${ }^{7}$ Ghosh, Subir (1991), Mass Media Today, Profile Publishers, Calcutta

${ }^{8}$ Mann, Doug (2008), Understanding society: a survey of modern social theory, Oxford University Press,

${ }^{9}$ http://www.britannica.com/topic/public-opinion (As viewed on 13.01.2016)

${ }^{10}$ Mansfield, Edward D., Sisson, Richard (ed) (2004), The Evolution of Political Knowledge: Theory and Inquiry in American Politics, The Ohio State University Press, Columbus

${ }^{11} \mathrm{http}: / /$ www.britannica.com/topic/public-opinion(As viewed on 13.01.2016)

${ }^{12}$ Snow, Nancy (2003). Information War: American Propaganda, Free Speech and Opinion Control Since 9/11. Canada: Seven Stories. pp. 30-31

${ }^{13}$ Schama, Simon (2004), Citizens: A Chronicle of the French Revolution, Penguin 


\footnotetext{
${ }^{14}$ Palmer, P.A., (1936), Public Opinion in political theory in Wittke, C. (ed.) Essays in history and political theory: In honour of Charles Howard Mcllwain, Cambridge, MA: Harvard University Press, pp. 230-257

${ }^{15}$ Price, V., (1992), Public Opinion, Newbury Park, CA: Sage

${ }^{16}$ Vasquez, Gabriel M., Taylor, Maureen (2001), "Research perspectives on "the Public", In Heath, Robert Lawrence; Vasquez, Gabriel M. Handbook of public relations.SAGE.ISBN 978-0-7619-1286-6.

${ }^{17} \mathrm{http}: / /$ www.britannica.com/topic/public-opinion (As viewed on 13.01.2016)

${ }^{18}$ Kamath, M.V., (2005), Professional Journalism, Vikas Publishing House Pvt Ltd, New Delhi

${ }^{19}$ Meheta, D.S.,(1979), Mass Communication and Journalism in India, Allied Publishers Pvt. Limited, p 170
}

\section{Bibliography}

1. Carr, C.F. and Stevens, F.E. (1946), Modern Journalism, Sir Isaac Pitman \& Sons Ltd, London

2. Ryan, C (1991), Prime Time Activism: Media Strategies for Grassroots Organizing, South End Press, Boston

3. Nath, Shyam (2005), News, Audiences and Everyday Life, Authors Press, Delhi, pp 25-27

4. Schlesinger, P. (1987), Putting 'Reality' Together (2nd ed.), BBC News, Methuen, London

5. Bell, Allan, (1991), The Language of News Media. Oxford: Blackwell.

6. Shoemaker, P. and Reese, S.D. (1996) Mediating the Message. London: Longman. 